\title{
The Influence of Locus of Control and Financial Knowledge to Employee Investing Decision PT. Pertamina (Persero) Branch of Padang
}

\author{
Halkadri Fitra'), Rosyeni Rasyid ${ }^{2)}$, Yuliza Susanti ${ }^{3)}$ \\ 1) Universitas Negeri Padang, Padang, Indonesia, $\square$ (e-mail) halkadri.feunp@gmail.com \\ 2) Universitas Negeri Padang, Padang, Indonesia, $\square$ (e-mail) rosyenirasyid@yahoo.com \\ 3) Universitas Negeri Padang, Padang, Indonesia, $\bowtie$ (e-mail) yulizasusanti11@gmail.com
}

\begin{abstract}
This study aims to determine the effect of Locus of Control and Financial Knowledge on Investment Decisions. The research population is all employees of PT. Pertamina (Persero) Branch of Padang and using Purposive technical Sampling so that obtained sample 43 people. The data used are primary data, obtained by interview method and questionnaire. Data analysis uses multiple regression and data processing methods use SPSS software version 16.0. The results showed that the variable Locus of Control and Financial Knowledge partially significant effect on Decision Invest employees PT. Pertamina (Persero) branch of Padang. The simultaneous test results also show that the variables of Locus of Control and Financial Knowledge have significant influence on employee investment decisions.
\end{abstract}

Keywords: financial knowledge, investment decision, and locus of control

\section{Introduction}

The rapid technological developments make everything change according to the times and make the consumer behavior higher. It creates unexpected large funding for technology needs to achieve selfexistence, the need to own a home or a car and the need for entertainment. These needs will also cause everyone to be motivated to collect some funds to meet those needs. To meet these needs everyone needs to work and earn income. Besides, with the increasing number of individual needs, it appears that various types of investments are offered to everyone in order to obtain profitable results in the future.

According to Tandelilin (2010) investment is a commitment to a number of funds or other resources that are done at this time, with the aim of obtaining some benefits in the future. Every individual basically needs investment, because the purpose of a person investing is to make some money, in the broadest sense is to improve the welfare. More specifically, there are several reasons why a person invests among others; to earn a decent living in the future, ease inflationary pressures, and the drive to save taxes (Tandelilin, 2010). But investing is not easy, one must be thorough enough to not lose or get stuck with a garbage investment, or even deceived by irresponsible parties. Therefore we must know in advance the types of existing investments, prospects and risks so that our money does not just disappear.

Many types of investments exist and each has its own risk. The type of investment chosen will greatly determine how much profit will be derived from the investment. According to Fahmi and Hadi (2011) known there are two forms of investment that is Real Investment and Financial Investment that can be an option. Real Investment is an investment in real assets that generally involves investing in tangible assets such as land, machinery, gold and buildings while financial investment is an investment in the form of written contract assets, such as common stock and bonds, including savings and deposits.

For investment in financial sector, some people have shifted from investing savings and time deposits to investing in the capital market because it no longer becomes an attractive investment because of the 
small return on investment. According to Tjiptono (2006), capital markets provide many benefits such as providing investment vehicles for investors while enabling diversification efforts, providing a key indicator for the country's economic trends, as an optimal allocation of funding resources, and as an investment alternative that provides potential benefits with calculated risks through openness, liquidity, and investment diversification.

Although there are many people who know the investment in the capital market in the form of financial assets, but not a few also choose to invest in real assets as seen from the results of surveys through questionnaires to employees of PT. Pertamina (Persero) Branch Padang which is where researchers conduct research, states that the majority of employees of PT. Pertamina (Persero) branch of Padang more interested to invest in real assets such as house, land, gold than investing in financial assets, as shown in table below:

Table 1 Recapitulation of total question of selection of employee investment PT. Pertamina (Persero) Branch of Padang

\begin{tabular}{lcccc}
\hline \multirow{2}{*}{ No } & Gender & \multicolumn{2}{c}{ Selection of Investment Type } & \multirow{2}{*}{ Total } \\
\cline { 3 - 4 } & & Real Asset & Financial Asset & \\
\hline 1 & Man & 27 & 5 & 32 \\
\hline 2 & Woman & 10 & 1 & 11 \\
\hline & Total & 37 & 6 & 43 \\
\hline
\end{tabular}

Source: Interview Result, 2018

Seeing investor's tendency in choosing form of investment, investment decision made by investor can be influenced by market behavior and investor behavior itself either rationally or irrational. This rational and irrational behavior is part of behavior finance. Nofsinger (2001) defines financial behavior (behavioral finance) that is studying how humans actually behave in a financial setting. Nofsinger also mentions that behavioral finance studies the psychological factors that will affect financial decision making, companies, and financial markets. The explanation is explained clearly that behavioral finance is an approach that explains how people make investments that are influenced by psychological factors. Along with Nofsinger, according to Manurung (2012) there are several psychological factors that influence investment decisions and results to be achieved. An investment analysis that uses the science of psychology and financial science is known by behavior or financial behavior (Behavior Finance). Among the factors that influence the investment decision are the different beliefs about the fate and factors of financial knowledge.

The first is that there is a difference of belief in the fate or all events that occur in a society they believe to be bad luck and luck or those who believe that all the events they are experiencing are derailed from their own efforts. In accordance with the concept of Robbins (2001) on how one can control his own destiny, which is famous for the concept of locus of control, namely as an action in which individuals connect events in their life with actions or forces from outside his control. The basic concept of Locus of Control is derived from the social learning theory developed by Patten (2005) in which locus of control is related to the level of one's beliefs about events, fate, fortune and destiny occurring in him, whether due to internal factors or external factors. Locus of control relates to a person's view or perception by looking at the conditions and predicting what will happen in the future in the decision taken. The second is the financial knowledge factor that also plays an important role in deciding investment planning, with the knowledge it has about how to manage and plan the finances that can provide benefits and avoid losing out. This is supported by the results of Pritazahara and Sriwidodo (2015) research which says financial 
knowledge becomes inseparable in one's life because financial knowledge is a useful tool for making financial decisions, but from experience in various countries still shows relatively less high.

Based on the conditions presented above, the researcher is interested to carry out the research and make the following problem formulation:

1. How the influence of Locus of Control on employee investment decisions PT. Pertamina (Persero) Branch of Padang?

2. How the influence of Financial Knowledge on employee investment decisions PT. Pertamina (Persero) Branch of Padang?

With the second formulation of the problem then the purpose of this study is to determine whether there is a significant influence between Locus of Control and Financial Knowledge of Employee Investment Decisions PT. Pertamina (Persero) Branch of Padang. To support the research objectives, the researcher approaches to several concepts, namely:

1. Behavioral Finance Theory

According to Barberis and Thaler (2003) in Bodie, Kane, and Marcus (2008) describes behavioral finance as a model of financial markets that emphasizes the potential implications of psychological factors that influence investor behavior. Furthermore Sewell (2010) defines Behavior Finance as "study of the influence of psychology on the bahaviour of financial practitioners and the subsequent effect on market". From the definition of Behavior Finance provided by Sewell, there are two interesting things addressed. First, investor behavior is an observational object. Individually, the psychological aspect of investors in looking at risk and return (return) would vary. Investor tolerance to risk (risk appetite) is always different. This observation of the psychological aspect is individually necessary to determine the securities that are appropriate to the psychological state of the investor at the time. And in another perspective, the observed results can be used as predictors of possible transactions that must be done. Second, investor behavior determines the market. Communally and jointly, the behavior of these investors will determine the price and stock capitalization. So the trend of movement of Composite Stock Price Index can be predicted with this Behavior Finance analysis. This will minimize the potential loss or risk borne by the investor.

2. Prospect Theory

One of the theories of decision making in the most famous uncertainty condition is the prospect theory. This theory was developed by two prominent scientists from the United States, namely Daniel Kahneman and Amos Tversky circa 1979. Daniel Kahneman then became the first and only psychologist who won the Nobel Economics in 2002 and became one of the greatest discoveries in the field of behavioral finance.

3. Investor Sentiment

Shleifer (2000) defines investor sentiment as a heuristic-based behavioral belief or a rule of thumb rather than Bayesian rationality in making investment decisions. This occurs when investor preferences and trust meet psychological evidence rather than a standard economic model.

4. Invest Decision

According to Sindhu and Kumar (2014) investment decisions generally mean the decisions made by investors as to where, how, and how much funds will be invested in various financial instruments with the aim of generating income or value appreciation. Investment decisions are also interpreted by Dewi and Iramani (2014) a policy or decision taken to invest capital in one or more assets for future gain or the problem of how one should allocate funds into investment forms that will be profitable in the future come. Here the concept of investment decisions is defined as the decisions taken by individual investors when investing in stocks. From the above understanding can be 
concluded that the investment decision is how investors allocate funds owned to be invested in financial instruments.

5. Locus of Control

The concept of locus of control was first proposed by Rotter in 1996 who is a social learning theorist. Locus of control can be interpreted as a person's perspective on an event whether he can or can't control the events that happen to him. Locus of control according to Kreitner and Kinicki (2001) consists of two constructs, namely internal and external, where if a person believes that what is happening is always in his control and always takes a responsible role in every decision including internal locus of control, while a person who believes that events in his life are beyond his control are included in the external locus of control.

6. Financial Knowledge

Hilgert and Hogarth (2003) argue that financial knowledge is the conceptual definition of financial literacy. So, financial knowledge is related to financial literacy or financial education. Financial knowledge can be channeled and can be understood well through financial education or financial literacy. According to Carolynne and Richard (2000) financial literacy it is a "meaning-making process" in which individuals use a combination of skills, resources, and contextual knowledge. From the above understanding it can be concluded that financial literacy is an individual decision making using a combination of several skills, resources, and contextual knowledge to manage information and make decisions based on the financial risks of the decision. While financial knowledge is a person's mastery of various things about the financial world (Kholillah \& Iramani, 2013).

Based on the description above, the hypothesis are:

H1: There is a significant influence of locus of control on investment decisions

$\mathrm{H} 2$ : There is a significant influence of financial knowledge on investment decisions.

Based on the research hypothesis, the conceptual framework of this research is as shown below:

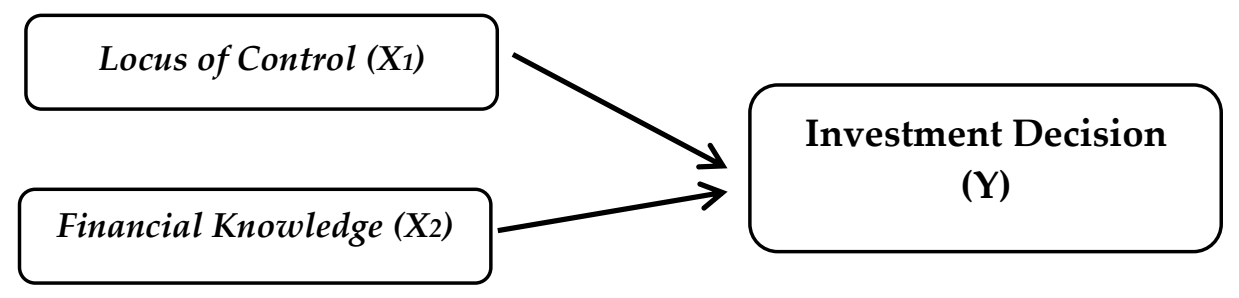

Figure 1 Conceptual framework

\section{Methods}

This type of research is classified as descriptive research. Research must involve in it a sequence of rational decision-making options (Sekaran, 2006). This research uses field research or descriptive survey and explanatory research that explains the casual relationship between research variables and test the previously formulated hypothesis by distributing questionnaires, where the questionnaire contains some structured questions answered by respondents related to the decision to invest.

Research conducted at PT. Pertamina (Persero) branch of Padang having its address at Jalan Veteran No. 60 Padang. The research population is all employees of PT. Pertamina (Persero) Branch of Padang and for sampling in this research used purposive sampling method; it's in taking basic sample based on 
certain criterion. The criteria used in sampling are employees who have made an investment and based on the criteria obtained by 43 employees.

Measurement of decision variables Investing $(Y)$ using two indicators namely returns, and risk, (Tandelilin, 2010). As for Locus of Control variable (X1) measured using internal locus of control indicator and external locus of control (Rotter, 1996) and Financial Knowledge (X2) variable measured using general personal finance knowledge, saving and borrowing, insurance and investment (Chen and Volpe, 1998).

The measurement technique applied is based on the rank or ranking of the questions presented, where the respondent chooses only one of the five alternatives used:

Table 2 Answer Score Each Statement

\begin{tabular}{lcc}
\hline No. & Statement & Score \\
\hline 1 & Very Agree & 5 \\
\hline 2 & Agree & 4 \\
\hline 3 & Less Agree & 3 \\
\hline 4 & Disagree & 2 \\
\hline 5 & Very Disagree & 1 \\
\hline
\end{tabular}

Source: Processed, 2018

This research uses multiple regression analysis model by enabling the approaching reality between the variables that exist and measure the influence between independent variables and dependent variables. With the equation as follows:

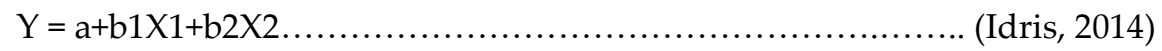

Where:

$$
\begin{aligned}
& \mathrm{Y}=\text { Investment Decision } \\
& \mathrm{X} 1 \quad=\text { Locus of Control } \\
& \mathrm{X} 2 \quad=\text { Financial Knowledge } \\
& \text { a } \quad=\text { Intercept } \\
& \text { b1 b2 b3 = Regression coefficient of independent variable } \\
& \text { e }=\text { error term }
\end{aligned}
$$

\section{Results and Discussion Validity test}

Arikunto (2006) explains that validity is a size measure that indicates the level of reliability or validity of a measuring instrument. To test the validity of the measuring instrument as a whole by correlating each item of the measuring instrument with the total score that is the sum of each score of the item. For $\mathrm{n}$ $=30>0.3640$ indicates that the study instrument is valid. From the SPPS printout seen is corrected item total correlation.

The decision to test the validity of the instrument is done by using the significance of 0.05 with the provision if the significance value $>0.05$ then the item is declared invalid and vice verse if the significance value $<0.05$ then the item is declared valid (Priyatno, 2012).

The result of the validity test is known that there are 7 items of invalid statement. This can be seen in the following table: 
Table 3 Test Results Validity of Research Instruments

\begin{tabular}{lcccc}
\hline \multicolumn{1}{c}{ Variable } & $\begin{array}{c}\text { Number of } \\
\text { Statements }\end{array}$ & Valid & $\begin{array}{c}\text { Not } \\
\text { Valid }\end{array}$ & Decision for not valid \\
\hline Investment Decision $(\mathrm{Y})$ & 12 & 11 & 1 & Item removed \\
\hline Locus of Control $(\mathrm{X} 1)$ & 19 & 16 & 3 & Item removed \\
\hline Financial Knowledge $(\mathrm{Y} 2)$ & 24 & 21 & 3 & Item removed \\
\hline TOTAL & 55 & 48 & 7 & \\
\hline
\end{tabular}

Source: Data on Calculation Result with SPSS, 2018

Based on table 3 it can be seen that for the variable $Y$ has 11 valid statement items and 1 invalid, the variable $\mathrm{X} 1$ has 16 valid statements and 3 invalid, while the $\mathrm{X} 2$ variable has 21 valid statement items and 3 invalid ones. Invalid statement discarded.

\section{Reliability Test}

Reliability test is used to test the consistency of the measuring instrument, whether the result is consistent or not if the measurement is repeated. The unqualified questionnaire instrument is inconsistent for measurement so that the measurement result can't be trusted. Test reliability is widely used in research that is using Cronbach's Alpha method (Priyatno, 2012). The summary of the reliability test of the research variables can be seen in the following table:

Table 4 Reliability Test Results of Research Instruments

\begin{tabular}{ccc}
\hline Variable & Cronbach's Alpha & Decision \\
\hline Investment Decision $(\mathrm{Y})$ & 0,724 & Reliable \\
\hline Locus of Control $(\mathrm{X} 1)$ & 0,811 & Reliable \\
\hline Financial Knowledge $(\mathrm{X} 2)$ & 0,879 & Reliable \\
\hline
\end{tabular}

Source: Data on Calculation Result with SPSS, 2018

Based on the results of the test reliability in table 3.4, can be seen if the value of Cronbach's Alpha for Investment Decision instruments (Y) is 0.724, instruments Locus of Control (X1) 0.811 and Financial Knowledge instrument (X2) 0.879. It shows that the value of cronbach's alpha is greater than the general rule greater than or equal to 0.70 (Nunnally and Ira, 1994). Thus, it can be concluded all the research instruments can be said reliable.

\section{Normality Test}

Based on the results of the normality test in Appendix Table 1 shows the significant value is 0.608 . With these results it can be stated that the data used in the study has been normally distributed, because the value of significance (see Asymp.sig value) from the normality test of 0.05 .

\section{Multicollinearity Test}

Based on the results in Appendix Table 2 shows the tolerance values of Free Variables is $>0.1$. Then the VIF value of Free Variable $<10$, it can be concluded that there is no multicollinearity in the regression model.

\section{Heterocedasticity Test}

Based on the output in Appendix table 3 it is known that the significance value of Locus of Control (X1) is 0.847 , Financial Knowledge (X2) of 0.447 and the two variables have significance value greater than 0.05 meaning no heterokedasticity on $\mathrm{X} 1$ and $\mathrm{X} 2$. 


\section{Multiple Regression Analysis}

Based on the results contained in Appendix Table 4 can be formulated multiple linear regression equation as follows:

$\mathrm{Y}=-15,106+0,171 \mathrm{LoC}+0,400 \mathrm{FK}$

From the above equation it can be read that:

1. The value of constant value is $-15,106$ shows, without the existence of locus of control variable (X1), and financial knowledge (X2), then investment decision (Y) equal to $-15,106$.

2. The locus of control variable has a positive regression coefficient of 0.171 . It identifies that any increase in the locus of control variable (X1), will result in an increase in investment decision of 0.171 units.

3. The financial knowledge $(X 2)$ variable has a positive regression coefficient of 0.400 . It identifies that any increase in locus of control variable (X1), will result in an increase in investment decision of 0.400 units.

\section{Determinant Coefficient Test $\left(\mathbf{R}^{2}\right)$}

In Appendix Table 5 it can be seen that the value of $\mathrm{R}^{2}$ obtained is 0.512 . That is, investment decisions can be explained by independent variables, namely locus of control and financial knowledge of 51.20\%. The remaining $48.80 \%$ is explained by other variables not included in this study.

\section{Test F Statistics}

Based on Appendix Table 6 indicates that the F value counted 20.953 with a significance level of 0.000 $<0.05$. This means that there is a significant influence simultaneously between all independent variables to the dependent variable. Thus, it can be concluded that this model is worthy to be tested. Regression Value In Appendix Table 5 of 0.715 also shows that two independent variables (X1 = Locus of Control and $\mathrm{X} 2$ = Financial Knowledge $)$ have a strong influence on the dependent variable ( $\mathrm{Y}=$ Investment Decision).

\section{Hypothesis Test ( $\mathrm{T}$ test)}

1. Hypothesis 1

Based on H1, the locus of control significant effect on employee investment decisions PT. Pertamina (Persero) branch of Padang. The test results are supported by a significant value of $0.014<0.05$. Means it can be concluded that the variable locus of control significant effect on employee investment decisions PT. Pertamina (Persero) branch of Padang.

H1 relevance with research Perry and Morris (2005) which states that the locus of control affect the financial management. In this study the financial management in question is the decision to invest. This fund is also in line with research Triana et al (2012) found that the locus of control has a simultaneous influence on one's behavior to control an event that occurs in him. Adi and Mardiasmo (2002) research also stated that locus of control influences one's attitude in dealing with events that happen to him. In line with McGee's research (2013) research, the internal locus of control is very influential in achieving greater profitability by believing in its own strength, whereas the internal locus of control produces ineffective benefits.

2. Hypothesis 2

Based on H2, financial knowledge significant effect on employee investment decisions PT. Pertamina (Persero) branch of Padang. The test results are supported by a significant value of $0.000<0.05$. Means it can be concluded that the variable financial knowledge significant effect on employee investment decisions PT. Pertamina (Persero) branch of Padang. 
H2 relevance with the research Hastings et al (2010) that financial knowledge is very important for someone to manage his personal finances and make it easier for someone to decide something about their financial welfare. The financial means is the decision to invest. This result is also reinforced by Yulianti and silvy (2013) states that financial knowledge and financial experience affect the behavior of family financial investment planning. The attitude of the financial manager moderates and reinforces the influence of financial knowledge and does not moderate the financial experience of the family financial investment planning behavior. And according to the research According to Lusardi (2008) suggests that low financial knowledge affect the future financial planning, while ignorance about the basic concept of finance can be associated with low investment planning.

\section{Conclusions}

1. Locus of control significant effect on employee investment decisions PT. Pertamina (Persero) branch of Padang. This is evidenced by the results of data processing using SPSS version 16 programs obtained significant value smaller than 0.05 that is equal to 0.014 .

2. Financial knowledge has a significant effect on employee investment decisions PT. Pertamina (Persero) branch of Padang. This is evidenced by the results of data processing using SPSS version 16 programs obtained significant value smaller than 0.05 is 0.000 .

\section{References}

Adi N, H, C, T. \& Mardiasmo. (2002). Analisis pengaruh strategi institusi, budaya institusi, dan conflict of interest terhadap budgetary slack. Jurnal Ekonomi dan Bisnis Indonesia. 17(1).

Ahmad, Z. (2010). Pengaruh biaya produksi dan penerimaan terhadap pendapatan petani padi sawah di Loa Gagak kabupaten Kutai Kertanegara. Jurnal EPP 7(1).

Al Haryono, J. (2005). Dasar-Dasar Akuntansi. Edisi 6.Yogyakarta: Sekolah Tinggi Ilmu Ekonomi YKPN.1.

Andrew, V. \& Nanik, L. (2014). Hubungan faktor demografi dan pengetahuan keuangan dengan perilaku keuangan karyawan swasta di Surabaya. FINESTA.02(02).

Arikunto, S. (2006). Metode Penelitian Kualitatif. Jakarta: Bumi Aksara.

Barberis, N. and Thaler, R. 2003. A Survey of behavioral finance, handbook of the economics of finance.

Bodie, Z., Kane, A., and Marcus, A, J. (2008). Investments. McGraw-Hill International Edition, Seventh Edition.

Brigham, E. F. \& Joe,1 F. H. (2010). Dasar-dasar Manajemen Keuangan. Edisi Sepuluh. Terjemahan oleh Ali Akbar Yulianto. Buku Dua. Jakarta: Salemba Empat.

Brownell,P. (1982). The role of accounting data in performance evaluation, budgetary participation, organizational effectiveness. Journal of accounting research, 20.

Carolynne, L.J M. \& Richard, MS. W. (2000). Conceptualizing financial literacy. Business School Research Series.

Chen, H. dan Ronald, P. V. (1998). An analysis of personal financial literacy among college student. Journal of Economics 22, 65-78.

Christanti, N. \& Mahastanti, L. A. (2011). Faktor-faktor yang dipertimbangkan investor dalam melakukan investasi. Jurnal Manajemen Teori dan Terapan.

Crider, A. B.(2003). Psychology. Scott, Foresm an \& Company.

Darmadji, T. \& Hendy, M. F. (2006). Pasar Modal di Indonesia Pendekatan Tanya Jawab. Jakarta: PT Salemba Empat.

Dewi, A. W. \& Iramani. (2014). Experienced study regret, risk tolerance, overconfidence and risk perception on investment for economic lecturers. Journal of Business and Banking 4(1), 55-66. 
Dhiraj, J. \& Nikhil, M. (2012). Impact of demographic factors on investment decision of investors in rajasthan. Journal of Arts, Science \& Commerce E-ISSN 2229-4686 ISSN 2231-4172.

Eduardus, T. (2010). Portofolio dan Investasi. Kanisius.

Fahmi \& Hadi. (2011). Teori Portofolio dan Analisis Investasi. Edisi 2. Bandung:Alfabeta

Ghozali, I. (2005). Aplikasi Analisis Multivariate dengan Program SPSS. Edisi Ketiga. Semarang: Badan Penerbit Universitas Diponegoro.

Hastings, J., Olivia, S. M. \& Eric, C. (2010). Fees, Framing, and financial literacy in the choice of pension managers. Pension Research Council Working Paper, Wharton School Summer.

Hilgert, M. A., Jeanne, M. H., \& Beverly, S. (2003). House hould finance : the connection between knowledge and behavior. Federal Reserve Bulletin, 87 (7), Hlm 300-322.

Hoffmann, A., Eijie, J. \& Jager, W. (2006). Individual Investors' Needs and Conformity Behavior: WorkingPaper.

Ida, \& Dwinta, C. Y. (2010). Pengaruh locus of control, financial knowledge dan income terhadap personal financial management behavior. Jurnal Bisnis danAkuntansi , 12(3).

Idris. (2010). Aplikasi Model Analisis Data Kuantitatif dengan Program SPSS Edisi Revisi III. Fakultas Ekonomi Universitas Negeri Padang.

Jones, G. E. \& M. J. Kavanagh. (1996). An experimental examination of the effects of individual and situational factors on unethical behavioral intentions in the workplace. Journal of Business Ethics, 15 (5), 511-523.

Jones, C.P. et al. (2009). Invesment: Analysis and Management, Indonesian Adaption. Salemba Empat \& John Willey.

Jogiyanto, H. (2013). Teori Portofolio dan Analisis Investasi. Edisi Kedelapan Yogyakarta: BPFE.

Justine, H. \& Olivia, S. M. (2010). How Financial Literacy and Impatience Shape Retirement Wealth and Investment Behaviors. Brown Universityand NBER.

Kholillah, N. A., \& Iramani, R. (2013). Studi financial management behavior pada masyarakat Surabaya. Journal of Business and Banking , 3(1): 69-80.

Kreitner R, \& Kinicki, A. (2001). Organizational Behavior, Fifth Edition, International Edition, Mc Graw-Hill companies. Inc.

Lefcourt, H.M. (1982), Locus of Control. London. Lawrence Erlbaum Associates.

Lubna, R. et al. (2012). Impact of psychological factors on investment decision making mediating by risk perception: a conceptual study. Middle-East Journal of Scientific Research 12 (6): 789-795, 2012 ISSN 1990-9233.

Lusardi, A. (2008). Household saving behavior: The role of financial literacy, information, and financial education programs. NBER Working Paper13824.

Manurung, A. H. (2012). Teori Perilaku Keuangan. PT Adler Manurung Press.

McGee. (2013). How the perception of control influences unemployed job search. Department of Economics Simon Fraser University.

Nofsinger, J. R. (2001). Investment Madness: How Psychology Affects You Investing and What to Do About It. New Jersey: Prentice Hall.

Patten, M.D. (2005). An analysis of the impact of locus of control on internal auditor job performance and satisfaction. Managerial Auditing Journal, 20.

Perry, V. G. \& Marlene, D. M. (2005). Who is control? the role of self perception, knowledge, and income in explaining con sumer financial behaviour. Journal of Personal finance, 8.

Ricchiardi, V. (2005). A research starting point for the new scholar: a unique perspective of behavioral finance. Journal in Behavioral.

Pritazahara, R. and U. Sriwidodo. (2015). Pengaruh pengetahuan keuangan dan pengalaman keuangan terhadap perilaku perencanaan investasi dengan self control sebagai variable moderating. Jurnal Ekonomi dan Kewirausahaan 15. 
Priyatno, D. (2012). Cara Kilat Belajar Analisis Data dengan SPSS 20. Edisi Kesatu. Yogyakarta: ANDI.

Putra, P. S. et al. (2015). Pengaruh tingkat literasi keuangan, experienced regret, dan risk tolerance pada pemilihan jenis investas. Journal of Business and Banking.

Putri, N. M. D. R. \& Henny, R. (2017). Pengaruh tingkat financial literacy dan faktor sosiodemografi terhadap perilaku keputusan investasi individu. ISSN 2337-3067 E-Jurnal Ekonomi dan Bisnis Universitas Udayana 6(9).

Rasyid, R. (2012). Analisis Tingkat literasi keuangan mahasiswa program studi manajemen Fakultas Ekonomi Universitas Negeri Padang. JurnalKajian Manajemen Bisnis,1(2)

Robbins, S. P. (2001). Perilaku Organisasi: Konsep, Kontroversi, Aplikasi, Jilid 1, Edisi 8, Jakarta: Prenhallindo.

Robbins, P. Stephen. 2003. Organization Behaviour : Concept, Controversies, Aplications. Seventh Edition. Prentice Hall Inc.

Rotter, J. B. (1966). Generalized expectancies for internal versus external control of reinforcement. Pshycological Monographs, 80.

Sardogan E. M., Kaygusuz, C. ve Karahan, T. F. (2006). A human relations skills training program, university students' locus of control levels, Mersin University. Journal of the Faculty of Education, 2 (2), 184-194

Selim, A. \& Asiye, N. Z. (2016). Influence of financial literacy and risk perception on choice of investment. Procedia - Social and Behavioral Sciences 235.

Senduk, S. (2004). Seri Perencana Keuangan Keluarga: Mencari Penghasilan Tambahan. Jakarta: Alex Media Komputoindo.

Sewell, M. (2010). Behavioural Finance. University of Cambridge

Shefrin, H. (2000). Beyond Greed and Fear: Understanding Behavior Finance and The Psychology of Investing.

Shefrin, H. (2007). Behavioral Corporate Finance International Edition. Singapore : McGraw-Hill.

Sindhu, K.P. \& Rajitha, K. (2014). Influence of risk perception of investors on investment decisions: an empirical analysis. Journal of Finance and Bank Management 2(2).

Solvic, P. (1972). Information processing, situation specifity and the generality of risk taking behavior. Journal of Personality and Social Psychology, 22, 128-134.

Strauser, D. R., Ketz, K. and Keim, J. (2002). The Relationship Between Self-Efficacy, Locus of Control and Work Personality. Journal of Rehabilitation, 68, 20-26.

Sugiyono. (2013) Metode Penelitian Kuantitatif Kualitatif Dan RED. Penerbit: Alfabeta : Bandung.

Suliyanto. (2011). Ekonometrika Terapan: Teori dan Aplikasi dengan SPSS. Yogyakarta: ANDI.

Tandelilin, E. (2010). Portofolio dan Investasi : Teori dan Aplikasi, Edisi Pertama: Penerbit Kanisius.

Triana, Y. \& Putra, W. E. (2012). Pengaruh partisipasi anggaran, budget emphasis, dan locus of control terhadap slack anggaran. Jurnal Binar Akuntansi.

Uma, S. (2006). Metodologi Penelitian untuk Bisnis, Edisi 4, Buku 1, Jakarta: Salemba Empat.

Welly. et al. (2015). Analisis pengaruh literasi keuangan terhadap keputusan investasi di STIE Multidata Palembang. Jurnal Ilmu Ekonomi danManajemen STIE MDP.

Yulianti, N. \% Silvy, M. (2013). Sikap pengelola keuangan dan perilaku perencanaan investasi keluarga di Surabaya. Journal of Business and Banking, 3(1).

Zebua, A.S dan Nurdjayadi, R.D. (2001). Hubungan antara konformitas dan konsep diri dengan perilaku konsumtif pada remaja putri. Jurnal Phronesis .3 (6).72-82.

https://ekonomi.kompas.com/read/2015/06/10/150500126/Masyarakat.Indonesia.Masih.Takut.Investasi.di. Pasar.Modal. Accessed on 16 November 2017.

https://www.harianhaluan.com/news/detail/61041/sumbar-urutan-14-investor-terbanyak. Accessed on 16 November 2017.

https://www.liputan6.com/bisnis/read/2393888/transaksi-saham-di-sumatera-barat-capai-rp-131-triliunper-bulan. Accessed on 16 November 2017. 
https://www.irtsbloger.blogspot.co.id/2015/04/pengertian-behavior-finance.html. Accessed on 16 November 2017 